\title{
KEDUDUKAN DAN KEWENANGAN \\ MAJELIS PERMUSYAWARATAN RAKYAT DALAM ERA REFORMASI
}

\author{
Ah. Mujib Rohmat \\ Anggota DPR-RI Komisi IX \\ Email: rofiq.simpati@gmail.com
}

\begin{abstract}
Amendment 1945 to the beginning of the Reformation (1999-2002) led to a fundamental change in the position and authority of the Assembly. When the previous General Assembly is the highest state institutions with enormous power turned into state institutions "normal" position in line with other state institutions such as the Parliament, the President, and the Supreme Court. When the previous General Assembly has the authority so large that after the changes, the authority is reduced, no longer authorized to elect the President and Vice President, the President and / or Vice President in his tenure as easy, and organize the lines of state policy (including guidelines on therein).

The decline position and a reduction in the authority of the Assembly is a positive impact on the state system and our democracy. With the position of the Assembly in line with the institutions of other countries then realized mutual control and balance (checks and balances) between branches of state power that can be prevented or minimized the abuse of authority, violation of the constitution, and the attitude / authoritarian and repressive policies of a state institution. Reduced authority of the General Assembly so that it no longer has enormous power, even indefinitely have a positive impact, namely to prevent potential violations of constitutional or human rights as well as the development of democratic life quality.
\end{abstract}

Keywords: Change of 1945, the Assembly, and the position of authority, the state system

\begin{abstract}
Abstrak
Perubahan UUD 1945 pada awal era Reformasi (1999-2002) menyebabkan perubahan fundamental terhadap kedudukan dan kewenangan MPR. Apabila sebelumnya MPR merupakan lembaga tertinggi negara dengan kekuasaan yang sangat besar berubah menjadi lembaga negara "biasa" dengan kedudukan sejajar dengan lembaga negara lainnya seperti DPR, Presiden, dan MA. Apabila sebelumnya MPR mempunyai kewenangan yang sangat besar maka setelah perubahan, kewenangannya sangat berkurang, tidak lagi berwenang memilih Presiden dan Wakil Presiden, memberhentikan Presiden dan/ atau Wakil Presiden dalam masa jabatannya secara mudah, dan menyusun garisgaris besar haluan negara (termasuk GBHN di dalamnya).

Penurunan kedudukan dan pengurangan kewenangan MPR tersebut membawa dampak positif bagi sistem ketatanegaraan dan demokrasi kita. Dengan kedudukan MPR yang sejajar dengan kedudukan lembaga-lembaga negara lainnya maka terwujud saling mengontrol dan mengimbangi (checks and balances) antar cabang kekuasaan negara sehingga dapat dicegah atau diminimalisir penyalahgunaan wewenang, pelanggaran konstitusi, dan sikap/kebijakan represif dan otoritarianisme sebuah lembaga negara. Berkurangnya kewenangan MPR sehingga tidak lagi mempunyai kekuasaan yang sangat
\end{abstract}


besar, bahkan tanpa batas membawa dampak positif, yakni mencegah terjadinya potensi pelanggaran konstitusi atau HAM serta dapat dikembangkannya kehidupan demokrasi yang lebih berkualitas.

Kata Kunci: Perubahan UUD 1945, Majelis Permusyawaratan Rakyat, kedudukan dan kewenangan, sistem ketatanegaraan.

\section{A. PENDAHULUAN}

Salah satu lembaga negara dalam sistem ketatanegaraan Republik Indonesia adalah Majelis Permusyawaratan Rakyat Republik Indonesia (MPR RI). Sebelum perubahan UUD 1945 pada awal era Reformasi (1999-2002), kedudukan MPR merupakan lembaga tertinggi negara dengan kekuasaan yang sangat besar. Hal tersebut mengacu pada Pasal 1 ayat (2) UUD 1945 sebelum perubahan, "Kedaulatan adalah di tangan rakyat, dan dilakukan sepenuhnya oleh Majelis Permusyawaratan Rakyat'." Dari ketentuan tersebut diketahui bahwa pelaksanaan kedaulatan rakyat di negara Indonesia di berada dalam satu tangan atau badan, yakni MPR. ${ }^{1}$

Padmo Wahjono merumuskan bahwa di negara Republik Indonesia diambil pola dasar bahwa kedaulatan secara penuh diwakilkan/ dilakukan oleh suatu lembaga yang bernama MPR. Kepada lembaga inilah segala sesuatu kegiatan kenegaraan harus dipertanggungjawabkan, baik kewenangan-kewenangan yang sesuai dengan teori Montesquieu maupun kewenangan-kewenangan lainnya di bidang kenegaraan yang tumbuh setelah zamannya Montesquieu. ${ }^{2}$

Atas dasar rumusan Pasal 1 ayat (2) UUD 1945 tersebut, dikembangkan pengertian sebagaimana diuraikan dalam Penjelasan Umum UUD 1945 yang oleh Dekrit Presiden tanggal 5 Juli 1959 dijadikan bagian yang tak terpisahkan dari naskah UUD 1945, yaitu bahwa Presiden bertunduk dan bertanggung jawab kepada MPR. Karena itulah, selama ini dimengerti bahwa MPR merupakan lembaga yang paling tinggi, atau biasa disebut sebagai lembaga tertinggi negara, sehingga wajar bahwa keberadaannya diatur paling pertama

1 Sri Soemantri, 1977, Tentang Lembaga-lembaga Negara Menurut UUD 1945, Alumni, Bandung, hlm. 85.

2 Padmo Wahjono, 1986, Negara Republik Indonesia, Rajawali Pers, Jakarta, hlm. 112. dalam susunan UUD 1945. ${ }^{3}$ Penempatan MPR sebagai lembaga tertinggi negara dikukuhkan dengan Ketetapan MPR Nomor VI/MPR/1973 tentang Kedudukan dan Hubungan Tata Kerja Lembaga Tertinggi Negara dengan/atau Antar Lembaga-lembaga Tinggi Negara. ${ }^{4}$

Bahkan Penjelasan Pasal 3 UUD 1945 sebelum perubahan merumuskan antara lain, "Oleh karena Majelis Permusyawaratan Rakyat memegang kedaulatan negara, maka kekuasaannya tidak terbatas....". Dengan demikian UUD 1945 sebelum perubahan memposisikan MPR sebagai lembaga yang mempunyai kekuasaan tidak terbatas.

Kekuasaan MPR yang sangat besar terlihat dari tugas dan wewenangnya yang diatur dalam Pasal 3 dan Pasal 6 ayat (2) UUD 1945 sebelum perubahan, yakni menetapkan Undang-Undang Dasar, menetapkan garis-garis besar daripada haluan negara, dan memilih Presiden dan Wakil Presiden. ${ }^{6}$ Selain itu, MPR juga berwenang memberhentikan Presiden dan/atau Wakil

3 Jimly Asshiddiqie, 2006, Perkembangan dan Konsolidasi Lembaga Negara Pasca Reformasi, Sekretariat Jenderal dan Kepaniteraan Mahkamah Konstitusi RI, Jakarta, hlm. 145.

4 Dalam Pasal 1 ayat (1) Ketetapan MPR tersebut dinyatakan bahwa "Yang dimaksud dengan Lembaga Tertinggi Negara dalam Ketetapan ini ialah Majelis Permusyawaratan Rakyat yang selanjutnya dalam Ketetapan ini disebut Majelis." Pasal 1 ayat (2) Ketetapan MPR ini menyebut lembaga-lembaga tinggi negara dengan rincian: Presiden, Dewan Pertimbangan Agung, Dewan Perwakilan Rakyat, Badan Pemeriksa Keuangan, dan Mahkamah Agung. Uraian lengkap Ketetapan MPR ini dapat dilihat dalam Himpunan Ketetapan MPRS dan MPR Tahun 1960 s/d 2000, penerbit Sekretariat Jenderal MPR RI, 2001.

5 Ibid., hlm. 4.

$6 \quad$ Ibid., hlm. 4, Pasal 3 UUD 1945 sebelum perubahan berbunyi, "Majelis Permusyawaratan Rakyat menetapkan Undang-Undang Dasar dan garis-garis besar daripada haluan negara". Pasal 6 ayat (2) UUD 1945 sebelum perubahan berbunyi, "Presiden dan Wakil Presiden dipilih oleh Majelis Permusyawaratan Rakyat dengan suara yang terbanyak." 
Presiden dalam masa jabatannya apabila Presiden dan/atau Wakil Presiden dianggap melanggar haluan negara yang ditetapkan UUD atau MPR (biasa disebut pemakzulan atau impeachment).

Perubahan UUD 1945pada awal era Reformasi, 1999-2002 telah mengubah secara mendasar sistem ketatanegaraan Indonesia, termasuk mengenai MPR. Dengan perubahan konstitusi tersebut, tidak lagi menempatkan MPR sebagai lembaga tertinggi negara yang sepenuhnya melaksanakan kedaulatan rakyat [Pasal 1 ayat (2)]. Artinya MPR tidak lagi sebagai sumber/lembaga/institusi kekuasaan negara yang tertinggi yang mendistribusikan kekuasaannya pada lembaga-lembaga negara yang lainnya. ${ }^{7}$

Terkait dengan ini, Jimly Asshiddiqie menyebutkan bahwa setelah perubahan UUD 1945, tidak dikenal lagi adanya lembaga tertinggi negara. Sesuai doktrin pemisahan kekuasaan (separation of power) berdasarkan prinsip checks and balances antara cabang-cabang kekuasaan negara, MPR mempunyai kedudukan yang sederajat dengan lembaga-lembaga negara lainnya. ${ }^{8}$

Perubahan ketentuan ini dalam rangka penataan ulang sistem ketatanegaraan Indonesia agar dapat diwujudkan secara optimal sistem ketatanegaraan yang menganut sistem saling mengawasi dan saling mengimbangi (checks and balances) antar lembaga negara dalam kedudukan yang setara, dalam hal ini antara MPR dan lembaga negara lainnya seperti Presiden dan DPR. ${ }^{9}$

Perubahan ketentuan konstitusi tersebut berarti terjadi perubahan fundamental dalam sistem ketatanegaraan kita, yakni dari sistem yang vertikal-hirarkis dengan prinsip supremasi MPR menjadi sistem yang horizontal-fungsional dengan prinsip saling mengimbangi dan saling mengawasi antarlembaga negara. ${ }^{10}$

7 Sekretariat Jenderal MPR, Loc. Cit., hlm. 4. Pasal 1 ayat (2) hasil perubahan berbunyi, "Kedaulatan berada di tangan rakyat dan dilaksanakan menurut UndangUndang Dasar."

8 Jimly Asshiddiqie, 2006, Perkembangan dan Konsolidasi ..., Op. Cit., hlm. 147.

9 Sekretariat JenderalMPR,2005, PanduanPemasyarakatan Undang-Undang Dasar Negara Republik Indonesia Tahun 1945, Sekretariat Jenderal MPR, Jakarta, hlm. 50.

10 Ibid.
Selain penurunan kedudukan dari lembaga tertinggi negara menjadi lembaga negara saja, perubahan konstitusi juga mengubah kewenangan MPR dalam bentuk pengurangan kewenangan sehingga menyebabkan MPR tidak sekuat seperti ketika UUD 1945 sebelum diubah. Perubahan UUD 1945 menyebabkan MPR tidak lagi berwenang mengeluarkan garis-garis besar daripada haluan negara dan tidak lagi berwenang memilih Presiden dan Wakil Presiden.

Setelah perubahan konstitusi mengenai MPR berselang sekitar 12-13 tahun lalu (perubahan konstitusi mengenai MPR terjadi pada 2001 dan 2002), muncul gagasan perlunya dilakukan perubahan mengenai MPR. Substansi wacana tersebut antara lain adanya kehendak untuk mengembalikan kedudukan MPR sebagai lembaga tertinggi negara, diberlakukannya kembali Garisgaris Besar Haluan Negara (GBHN) yang dibuat oleh MPR, dan peningkatan peranan MPR dalam penyelenggaraan negara.

Pakar hukum tata negara Yusril Ihza Mahendra menggagas untuk mengembalikan kedudukan MPR sebagai lembaga tertinggi negara. Menanggapi gagasan pakar hukum tata negara tersebut, Ketua MPR (saat itu) Sidharto Danusubroto menyatakan bahwa gagasan tersebut harus dikaji dan dipertimbangkan plus minusnya mengembalikan MPR sebagai lembaga tertinggi negara. Ketua MPR sendiri condong dilakukan amandemen agar kedudukan MPR menjadi lembaga tertinggi pada periode selanjutnya. ${ }^{11}$

Ketua Umum DPP Partai Golkar Aburizal Bakrie menyatakan, bahwa Partai Golkar menginginkan adanya platform yang mewadahi bangsa Indonesia untuk 25 tahun, 50 tahun dan sampai 100 tahun mendatang. la meneruskan akibat tidak adanya GBHN maka kebijakan nasional hanya menjadi domain Presiden terpilih dan hanya menjangkau 5 tahun sesuai masa jabatan Presiden. Kalaupun terpilih lagi selama 2 periode hanya menjabat selama 10 tahun. Jangkauan 10 tahun ini tentunya sangat singkat untuk menyusun program pembangunan nasional. Karena itulah perlu adanya penyusunan program nasional jangka panjang siapapun Presiden yang

11 http://kajianketatanegaraan.mpr.go.id/?p=109, diunduh pada 11 Juli 2014. 
menjabatnya. ${ }^{12}$ Dari pernyataannya mengenai pentingnya platform, dapat disimpulkan bahwa Partai Golkar menginginkan adanya Garis-garis Besar Haluan Negara (GBHN).

Menjelang berakhirnya anggota MPR periode 2009-2014, MPR menyelenggarakan sidang paripurna pada akhir September 2014 di Jakarta. Salah satu hasil kerja Panitia Ad Hoc II BP MPR yang disahkan sidang paripurna tersebut adalah tujuh rekomendasi untuk MPR periode berikutnya. Rekomendasi tersebut antara lain perubahan UUD 1945 dimana salah satu materinya adalah penguatan MPR sebagai lembaga dalam mengubah, menetapkan, dan menafsirkan UUD 1945. ${ }^{13}$ Secara lengkap rekomendasi hasil kajian Tim Kerja Kajian Sistem Ketatanegaraan Indonesia MPR tersebut adalah "penguatan MPR sebagai lembaga negara yang mempunyai kewenangan tertinggi dalam mengubah, menetapkan, menafsirkan UndangUndang Dasar, dan memberikan arah kebijakan kepada lembaga-lembaga negara lainnya." 14

Perkembangan pemikiran mengenai MPR setelah perubahan konstitusi sekitar 12 dan 13 tahun lalu merupakan perwujudan pergeseran dan perubahan sikap dan pandangan mengenai MPR. Apabila dulu MPR secara sadar diturunkan kedudukan dan dikurangi kewenangannya oleh MPR itu sendiri, sekarang muncul kembali semangat dan gagasan untuk memperkuat kembali MPR dalam bentuk mengembalikan kedudukan dan kewenangannya seperti sebelum diubah melalui perubahan konstitusi.

Perubahan pemikiran ini sangat penting untuk mendapat perhatian karena apabila hal tersebut dilakukan maka akan terjadi perubahan penting dalam sistem ketatanegaraan Indonesia kembali. Perubahan tersebut tentu akan berdampak cukup besar dalam perubahan penyelenggaraan negara,

12 Pernyataan tersebut disampaikan ketika Aburizal Bakrie memberikan sambutan pada pembukaan Focus Group Discussion (FGD) "Penguatan Sistem Presidensiil di Indonesia" yang diselenggarakan MPR bekerja sama dengan DPP Partai Golkar, 4 Desember 2013. Lihat http://kajian ketatanegaraan. mpr.go.id/?p=1048, diunduh pada 11 Juli 2014

13 "Tata Cara Pelantikan Presiden Dipertanyakan", Kompas, Selasa, 30 September 2014, hlm. 2.

14 Keputusan MPR Nomor 4/MPR/2014 tentang Rekomendasi Majelis Permusyawaratan Rakyat Republik Indonesia Masa Jabatan 2009-2014, hlm. 3-4. perubahan hubungan antarlembaga negara, dan bagi rakyat. Atas dasar itu, dipandang perlu dilakukan penelitian mengenai kedudukan dan kewenangan MPR pasca perubahan UUD 1945 dalam sistem ketatanegaraan Republik Indonesia.

Berdasarkan latar belakang yang telah diuraikan di atas, maka perumusan masalah dalam penelitian ini adalah sebagai berikut:

1. Bagaimana kedudukan dan kewenangan MPR pasca perubahan UUD 1945 setelah dilakukannya penurunan kedudukan dan pengurangan kewenangannya melalui perubahan UUD 1945?

2. Bagaimana dampak penurunankedudukan dan pengurangan kewenangan MPR tersebut terhadap MPR dan terhadap sistem ketatanegaraan RI?

\section{B. PEMBAHASAN}

\section{Kedudukan MPR Sebelum dan} Sesudah Perubahan UUD 1945

\section{a. Sebelum Perubahan UUD 1945}

Dalam sistem ketatanegaraan Republik Indonesia sebagaimana diatur dalam UUD 1945, MPR menempati kedudukan tertinggi. Kedudukannya mengatasi semua lembaga negara yang ada, seperti Presiden, DPR dan MA. Kedudukan tertinggi ini menempatkan dirinya sebagai Lembaga Tertinggi Negara sementara lembaga-lembaga negara lainnya yang ada, yaitu Presiden, DPR, DPA, MA, dan BPK menempati kedudukan di bawah MPR dan dimasukkan kategori sebagai Lembaga Tinggi Negara.

Oleh karena kedudukan MPR merupakan Lembaga Tertinggi Negara yang mengatur kedudukan dan kewenangan Lembaga-lembaga Tinggi Negara yang ada di bawahnya maka MPR dapat mengatur penyelenggaraan negara sesuai kehendak dirinya sendiri. Pengaturan semua lembaga negara tersebut dilakukan oleh MPR melalui perubahan dan penetapan UUD 1945 dan melalui berbagai ketetapan MPR yang menempati kedudukan tertinggi pula dalam hirarki 
peraturan perundang-undangan di Indonesia.

Oleh karena menempati kedudukan tertinggi maka MPR tidak dapat diawasi dan dikontrol serta dikendalikan oleh lembaga negara manapun dan oleh siapapun. Bahkan UUD sendiri tidak dapat mengontrol dan mengendalikan MPR karena MPRlah yang menentukan isi UUD serta sewaktu-waktu MPR dapat melakukan perubahan terhadap UUD sesuai keinginan dan kehendaknya.

Dengan konstruksi konstitusi yang demikian tidak dapat dilaksanakan sistem saling mengontrol dan mengawasi (checks and balances) antara lembaga-lembaga negara diluar MPR terhadap MPR. Oleh karena MPR-lah yang mengatur, mengendalikan, mengarahkan, dan menentukan nasib lembaga-lembaga negara selain dirinya. Betapapun mungkin kebijakan dan putusan MPR tersebut bertentangan dengan UUD, bertentangan dengan HAM dan demokrasi, namun tidak akan dapat dicegah atau dihalangi serta dibatalkan oleh lembaga negara lainnya.

Hal ini terjadi antara lain ketika MPR menetapkan Presiden Soekarno sebagai Presiden Seumur Hidup (1963). Walaupun putusan MPR tersebut bertentangan dengan UUD 1945 yang mengamanatkan masa jabatan Presiden adalah selama lima tahun dan dapat dipilih kembali, namun putusan MPR tersebut tetap diterbitkan dan berlaku tanpa dapat dcegah, dihalangi atau dibatalkan selama masa pemerintahan Soekarno.

Dalam perspektif demokrasi, konstruksi konstitusi yang demikian tentu tidak sehat karena tidak memberi ruang bagi berkembangnya secara leluasa demokrasi dan sistem saling mengontrol dan mengimbangi antarcabang kekuasaan negara. Situasi dan tingkat demokrasi di negara kita saat itu tergantung dari kemauan dan kehendak MPR yang diwujudkan melalui berbagai ketetapan MPR.

Oleh karenaUUD 1945 memberikan kedudukan tertinggi kepada MPR maka sistem yang dipakai dalam penyelenggaraan negara Indonesia sering juga disebut sebagai "Sistem MPR" atau "Supremasi MPR". Penamaan ini sebagai cermin dan wujud betapa tingginya kedudukan dan besarnya peranan MPR dalam sistem ketatanegaraan kita.

Walaupun secara normatifkonstitusional MPR menempati kedudukan tertinggi dalam struktur lembaga-lembaga negara di Indonesia, namun dalam riil politik kenegaraan, selama pemerintahan Presiden Soekarno dan Presiden Soeharto, peran MPR tidak sama persis dengan kedudukannya yang tertinggi tersebut. Presiden Soekarno dan Presiden Soeharto-lah yang mempunyai peranan paling menentukan, termasuk menentukan arah dan kebijakan serta keputusan yang akan diambil MPR. Hal ini dikarenakan UUD 1945 sendiri menentukan bahwa Presiden mempunyai kekuasaan yang dominan dan mempunyai kedudukan yang sangat kuat (executive heavy).

Presidenlah yang sesungguhnya secara riil mengatur MPR melalui kebijakan-kebijakan politiknya, termasuk dalam hal ini siapa yang dapat diangkat menjadi Utusan Daerah dan Utusan Golongan, siapa-siapa anggota MPR yang direncanakan untuk menjadi pimpinan MPR, dan materi-materi apa yang akan diputuskan oleh MPR. Selain itu, anggota MPR yang berasal dari anggota DPR hanya dapat menjadi anggota DPR setelah sebelumnya lulus penelitian khusus (screening) yang dilakukan secara ketat oleh pemerintahan (dipraktikkan dalam masa Presiden Soeharto). 


\section{b. Setelah Perubahan UUD 1945}

Kedudukan MPR setelah dilakukan perubahan UUD 1945 tidak lagi menempati sebagai Lembaga Tertinggi Negara. MPR mempunyai kedudukan yang sama dan sederajat dengan lembaga-lembaga negara lainnya (Presiden, DPR, DPD, MA, BPK, dan MK). MPR secara sukarela dan sadar telah menurunkan kedudukannya sendiri melalui perubahan konstitusi yang dilakukannya pada awal era Reformasi (1999-2002).

MPR pada awal era Reformasi menyadari sepenuhnya bahwa "Sistem MPR" yang dianut selama masa pemerintahan Soekarno dan Soeharto tidak sesuai dan tidak sejalan dengan prinsip demokrasi, keterbukaan, dan kebebasan. Atas dasar itu MPR melakukan perubahan mendasar dengan "menurunkan" derajat kedudukan MPR menjadi lembaga negara yang sejajar dan sama kedudukannya dengan lembaga negara lainnya, yang berbeda hanya pada tugas dan wewenangnya.

Seiring dengan itu, dalam perubahan konstitusi yang dilakukan MPR juga menempatkan UUD dalam posisi tertinggi menggantikan kedudukan MPR. UUD-lah yang mengatur, menentukan, membatasi, dan mengarahkan bagaimana kekuasaan negara dibagi kepada berbagai lembaga negara yang ada dalam sistem ketatanegaraan Indonesia, menjamin HAM dan pelaksanaan kedaulatan rakyat oleh rakyat sendiri, dan lain sebagainya.

Atas dasar itu, apabila UUD 1945 sering menganut "Sistem MPR" atau "Supremasi MPR" maka setelah perubahan, UUD 194 dikatakan menganut "Supremasi Konstitusi". Konstitusilah, dalam hal ini UUD 1945 , yang menempati kedudukan tertinggi dalam sistem ketatanegaraan kita. Dengan dianutnya "Supremasi Konstitusi" dalam UUD 1945 maka tidak ada lagi lembaga negara yang lebih tinggi kedudukannya dibandingkan dengan lembaga negara lainnya. Demikian pula tidak ada lagi sebuah lembaga negara yang sangat dominan atau bahkan memonopoli kekuasaan dan kedaulatan.

Dianutnya "Supremasi Konstitusi" dalam sistem ketatanegaraan kita sebagaimana dimuat dalam UUD 1945 merupakan wujud dari dianutnya paham Konstitusionalisme dalam konstitusi kita dan di negara kita. Konstitusionalisme adalah paham yang menempatkan konstitusi pada kedudukan tertinggi dalam negara, dan menjadikan konstitusi sebagai pedoman pokok yang pertama dalam mengatur dan membatasi kekuasaan dan penyelenggaraan negara. Konstitusionalisme yang kita anut berdasarkan pada hukum sesuai ketentuan Pasal 1 ayat (3) UUD 1945 yaitu "Negara Indonesia adalah negara hukum".

\section{Kewenangan MPR Sebelum dan Sesudah Perubahan UUD 1945}

\section{a. Sebelum Perubahan UUD 1945}

UUD 1945 sebelum mengalami perubahan pada awal era Reformasi mengatur dan memberikan kewenangan yang sangat besar kepada MPR. Bahkan Penjelasan UUD 1945 menyebutkan MPR mempunyai kekuasaan yang tidak terbatas.

Kewenangan MPR mengubah dan menetapkan UUD merupakan kewenangan yang dianggap standar untuk lembaga negara yang memiliki ciri khas seperti MPR. Kewenangan tersebut juga ada di lembaga-lembaga negara di berbagai negara lain karena memang harus ada sebuah lembaga negara yang diberi kewenangan oleh konstitusi untuk mengubah atau menetapkan UUD. 
Walaupun diberi kewenangan mengubah dan menetapkan UUD, selama masa keberlakuan UUD 1945 baik pada pemerintahan Soekarno maupun Presiden Soeharto, MPR belum pernah melakukan perubahan konstitusi. Pada masa pemerintahan Soekarno memang terjadi perubahan konstitusi, tetapi lebih tepatnya penggantian konstitusi dari UUD 1945 ke Konstitusi RIS.

Bahkan dalam masa Presiden Soeharto, sikap dan kebijakan Soeharto adalah tidak menghendaki munculnya ide/ gagasan perubahan UUD 1945. Penguasa melakukan tekanan terhadap pihak-pihak yang mempunyai gagasan atau pemikiran untuk mengubah UUD 1945. Dengan sikap demikian, selama pemerintahan Presiden Soeharto jarang sekali muncul pemikiran untuk mengubah konstitusi. Kalau pun muncul gagasan itu, lebih banyak dibicarakan di lingkungan sangat terbatas dan tidak dapat berkembang menjadi wacana publik.

Dalam pendekatan hukum, untuk mencegah dan mempersulit terjadinya perubahan UUD 1945, pemerintah melalui MPR menerbitkan Ketetapan MPR tentang Referendum. Berdasarkan ketetapan MPR ini, apabila muncul rencana mengubah UUD 1945 maka terlebih dahulu harus menggelar referendum untuk mengetahui sikap rakyat secara keseluruhan apakah setuju dengan adanya ide perubahan konstitusi tersebut. Apabila mayoritas rakyat menyetujui maka barulah usul perubahan tersebut diajukan ke MPR.

Dengan persyaratan yang sangat ketat untuk dapat diperolehnya suara persetujuan rakyat terhadap usul perubahan UUD 1945, maka dapat dipastikan sangat kecil kemungkinan usul perubahan konstitusi tersebut dapat disetujui dalam referendum sehingga tidak dapat diproses lebih lanjut ke MPR untuk dibahas. Kalau toh referendum meloloskan usul perubahan UUD 1945 maka kecil kemungkinan MPR dapat mengabulkan usul perubahan tersebut karena mayoritas anggota MPR berada di bawah pengaruh pemerintah.

Kewenangan MPR memilih, mengangkat, dan memberhentikan Presiden dan/atau Wakil Presiden dalam masa jabatannya merupakan salah satu kewenangan yang sangat besar. Dalam perjalanan MPR selama pemerintahan Presiden Soekarno, lembaga ini telah menetapkan Soekarno sebagai Presiden Seumur Hidup. Dalam masa pemerintahan Presiden Soeharto, MPR selalu memilih dan mengangkat Soeharto berkali-kali (tujuh kali) menjadi Presiden.

Proses pemilihan Presiden oleh MPR selama pemerintahan Soeharto menunjukkan bahwa lembaga ini tidak independen dalam melaksanakan kewenangannya, namun lebih banyak mengikuti kehendak Presiden Soeharto yang secara riil politik lebih berkuasa dibandingkan MPR. Oleh karena itu Soeharto selalu terpilin kembali menjadi Presiden selama tujuh kali sidang MPR dan baru bersedia berhenti dari kursi kepresidenannya setelah terjadi gejolak gelombang unjuk rasa besar-besaran di tanah air pada Mei 1998 lalu.

$\mathrm{Di}$ sisi lain, kewenangan memberhentikan Presiden dan/atau Wakil Presiden tidak dibatasi dengan kriteria atau ukuran yang jelas, tegas dan diatur dalam UUD 1945 yang menyebabkan seorang Presiden dan/atau Wakil Presiden dapat diberhentikan dalam masa jabatannya (impeachment). Dalam Penjelasan UUD 1945 hanya disebutkan apabila Presiden dan/atau Wakil Presiden dianggap melakukan pelanggaran terhadap haluan negara, maka ia dapat diproses untuk dilakukan pemakzulan (impeachment). Penafsiran apa yang disebut "haluan negara" tergantung dari MPR itu sendiri sehingga bersifat subyektif dan sesuai keinginan/kehendak MPR. oleh karena MPR juga memiliki bobot politik yang besar karena diisi oleh para anggota DPR yang berasal dari partai politik (plus ABRI dan TNI sampai dengan 2004) 
maka alasan pemberhentian seorang Presiden lebih banyak bersifat politik dibanding alasan hukum.

Atas dasar ketentuan dalam Penjelasan UUD 1945 itulah, dua Presiden Indonesia dalam masa jabatannya mengalami pemakzulan oleh MPR, yakni Presiden Soekarno dan Presiden Abdurrahman Wahid. Dalam pemberhentian kedua Presiden tersebut nampak jelas alasan politik lebih kuat dibanding alasan hukum.

Walaupun kewenangan MPR sangat besar sesuai UUD 1945, namun dalam praktik ketatanegaraan selama ini, sikap dan langkah yang diambil MPR sangat tergantung dari kehendak dan keinginan penguasa, dalam hal ini Presiden. Hal ini disebabkan secara riil politik, kekuasaan Presiden lebih besar dan lebih kuat dibandingkan MPR. Perkecualian akan terjadi dimana MPR mempunyai peran penting apabila Presiden mengalami proses pemerosotan kekuasaannya oleh penguasa baru yang tengah memperkuat kekuasaannya (dalam kasus pemakzulan Presiden Soekarno) atau ketika Presiden mempunyai kekuatan pendukung yang minim di MPR sementara kekuatan penentangnya menjadi mayoritas di MPR (sebagaimana terjadi dalam kasus pemakzulan Presiden Abdurrahman Wahid).

\section{b. Setelah Perubahan UUD 1945}

Setelah terjadi perubahan UUD 1945, kewenangan MPR dikurangi secara signifikan. Kewenangan yang dicabut dari MPR antara lain memilih Presiden dan Wakil Presiden serta tidak lagi menetapkan garis-garis besar daripada haluan negara (termasuk di dalamnya GBHN).

MPR tidak lagi berwenang memilih Presiden dan Wakil Presiden sebagai konsekuensi logis dari dipilihnya sistem pemiliham Presiden dan Wakil Presiden secara langsung oleh rakyat dalam perubahan UUD 1945 (tercantum dalam Pasal 6A). Dianutnya sistem pemilu
Presiden dan Wakil Presiden secara langsung merupakan langkah perubahan mendasar dalam sistem pemilu Presiden dan Wakil Presiden yang sebelumnya selalu dilakukan oleh MPR. Banyak kritik disampaikan ketika MPR yang hanya beranggotakan beberapa ratus orang tetapi memilih Presiden dan Wakil Presiden yang akan memimpin seluruh rakyat Indonesia selama lima tahun.

Dengan diberikannya wewenang rakyat untuk memilih Presiden dan Wakil Presiden secara langsung dalam pemilu maka Indonesia memasuki era demokrasi yang lebih berkualitas dibandingkan era sebelumnya. Bahkan Indonesia kini sejajar dengan negara-negara demokrasi yang telah menerapkan sistem pemilu Presiden secara langsung melalui pemilu.

Praktik Pemilu Presiden dan Wakil Presiden secara langsung oleh rakyat selama ini (telah berlangsung tiga kali, 2004, 2009, dan 2014) yang berlangsung demokratis, jujur dan adil, serta aman, dengan catatan masih ada beberapa kekurangan dan kelemahannya, membuktikan kesiapan rakyat Indonesia untuk melaksanakan haknya untuk memilih pemimpin secara baik. Melalui pemilu secara langsung oleh rakyat, Presiden dan Wakil Presiden telah diperkuat legitimasinya sehingga makin kuat kedudukannya.

MPR pasca perubahan UUD 1945 juga tidak berwenang lagi menetapkan garis-garis besar daripada haluan negara (termasuk GBHN). Kondisi ini juga merupakan konsekuensi logis dari sistem pemilu Presiden dan Wakil Presiden secara langsung oleh rakyat. Visi, misi, dan program kerja Presiden dan Wakil Presiden terpilih-lah yang menjadi acuan dan pedoman dalam penyusunan program pembangunan dan penyelenggaraan negara. ${ }^{15}$

15 Beberapa tahun terakhir ini muncul wacana disusunnya kembali program perencanaan pembangunan nasional semacam GBHN yang dibuat MPR. Hal ini termasuk salah satu Rekomendasi MPR Periode 2009-2014. 
MPR tetap diberi kewenangan melakukan pemakzulan terhadap Presiden dan/atau Wakil Presiden dalam masa jabatannya. Namun kewenangan ini telah diatur dan dibatasi dengan alasan konstitusional pemakzulan yang tercantum jelas dan tegas dalam UUD 1945 serta proses dan mekanisme yang melibatkan cabang kekuasaan yudikatif, yakni MK. Dengan adanya dua hal ini, MPR tidak dapat lagi melakukan pemakzulan atas dasar atau lebih besar alasan politiknya dibanding alasan hukum atau menggunakan alasan-alasan lain diluar alasan yang sudah ditetapkan UUD 1945.

UUD 1945 melibatkan MK dalam proses pemakzulan dengan tujuan untuk memperkecil atau bahkan menghilangkan alasan politik yang mungkin digunakan DPR. Selain itu juga sekaligus menguji pendapat DPR dengan batu uji konstitusi (hukum) dalam upaya memakzulkan Presiden dan/atau Wakil Presiden. Proses pemakzulan melalui MK menunjukkan kuatnya paham konstitusionalisme dalam sistem penyelenggaraan negara kita sekaligus melaksanakan amanat konstitusi bahwa Indonesia adalah negara hukum.

\section{PENUTUP}

\section{Kesimpulan}

a. MPR sebelum perubahan UUD 1945 berkedudukan sebagai Lembaga Tertinggi Negara yang mengatur dan membagi kekuasan negara kepada dirinya sendiri dan kepada lembaga-lembaga negara lain yang berkedudukan di bawahnya (disebut Lembaga Tinggi Negara). Kedudukan yang demikian tidak memungkinkan terjadinya saling mengontrol dan mengimbangi (checks and balances) antarcabang kekuasaan negara atau antarlembaga negara karena kedudukan yang tidak sejajar atau sama. Kedudukan tersebut juga berdampak pada tidak berkembangnya demokrasi dan kebebasan karena MPR yang menentukan arah dan kebijakan negara yang bersifat pokok.

b. MPR sebelum perubahan UUD 1945 mempunyai kewenangan yang sangat besar, bahkan menurut Penjelasan UUD 1945 MPR mempunyai kekuasaan yang tidak terbatas karena merupakan penjelmaan seluruh rakyat. Kewenangan yang demikian besar tidak memungkinkan terjadinya kontrol, pengawasan, dan keseimbangan oleh lembaga negara lain sebagaimana dianut dalam sistem demokrasi (checks and balances system). Dengan demikian dampaknya jelas akan merugikan rakyat karena demokrasi tidak berkembang secara baik dan terbuka pelanggaran HAM.

c. Kedudukan dan kewenangan MPR sebelum perubahan konstitusi tersebut membuka peluang terjadinya pelanggaran UUD 1945, pelanggaran hukum dan HAM tanpa dapat dicegah, dihalangi atau diatasi oleh lembaga negara lainnya. Praktikketatanegaraan yang dilakukan MPR baik pada masa Presiden Soekarno maupun Presiden Soeharto memperlihatkan adanya kebijakan dan putusan MPR yang tidak sesuai dengan UUD 1945 dan hanya menuruti kehendaknya sendiri atau menjadi alat legitimasi penguasa saat itu.

d. Setelah dilakukan perubahan UUD 1945, kedudukan MPR sudah sejajar dan sama dengan kedudukan lembaga-lembaga negara lainnya seperti Presiden dan DPR. Yang membedakan antarlembaga negara tersebut adalah tugas dan wewenangnya yang berbeda. Dengan konstruksi konstitusi yang mensejajarkan antarlembaga negara maka terwujud sistem saling mengontrol dan mengimbangi (checks and balances) antarcabang kekuasaan negara sehingga dapat dicegah atau diminimalisir 
penyalahgunaan wewenang atau pelanggaran konstitusi oleh lembaga negara.

e. Perubahan UUD 1945 juga menyebabkan berkurangnya kewenangan MPR sehingga tidak lagi mempunyai kekuasaan yang sangat besar yang dapat berpotensi melakukan pelanggaran konstitusi atau HAM. Dengan kewenangan yang telah dikurangi tersebut, MPR diharapkan dapat berperan secara lebih tepat di tengah dinamika kehidupan ketatanegaraan serta mampu mendorong meningkatnya kualitas demokrasi di Indonesia.

\section{Saran}

a. Perlu dilakukan penelitian dan pengkajian lebih mendalam mengenai pelaksanaan kedudukan dan kewenangan MPR pasca perubahan UUD 1945 beserta dampaknya dalam kehidupan kenegaraan. Dari penelitian tersebut diharapkan dapat dibentuk MPR yang lebih tepat di tengah kehidupan kenegaraan. Penyempurnaan tersebut dapat dilakukan melalui perubahan UUD 1945 kembali (Perubahan Kelima) bersama berbagai materi perubahan lainnya.

b. MPR perlu diberikan kewenangan yang lebih kuat terkait dengan Pancasila, UUD 1945, NKRI, dan Bhinneka Tunggal Ika. MPR perlu memberikan perhatian khusus dan melakukan agenda-agenda kerja yang sistematis tentang keempat hal pokok dalam bernegara dan berbangsa tersebut.

c. MPR perlu dipertimbangkan untuk mempunyai kewenangan menyusun program perencanaan pembangunan nasional model GBHN yang disesuaikan dengan sistem presidensial dan alam demokrasi.

\section{DAFTAR PUSTAKA}

\section{Buku}

Sri Soemantri, 1977, Tentang Lembaga-lembaga Negara Menurut UUD 1945, Alumni, Bandung. Padmo Wahjono, 1986, Negara Republik Indonesia, Rajawali Pers, Jakarta.

Jimly Asshiddiqie, 2006, Perkembangan dan Konsolidasi Lembaga Negara Pasca Reformasi, Sekretariat Jenderal dan Kepaniteraan Mahkamah Konstitusi RI, Jakarta.

Sekretariat Jenderal MPR, 2001, Himpunan Ketetapan MPRS dan MPR Tahun 1960 s/d 2000, Sekretariat Jenderal MPR RI. 2005, Panduan Pemasyarakatan Undang-Undang Dasar Negara

Republik Indonesia Tahun 1945, Sekretariat Jenderal MPR, Jakarta.

\section{Surat kabar}

“Tata Cara Pelantikan Presiden Dipertanyakan”, Kompas, Selasa, 30 September 2014, hlm. 2.

\section{Internet}

http://kajianketatanegaraan.mpr.go.id/?p=109, diunduh pada 11 Juli 2014.

http://kajian ketatanegaraan. mpr.go.id/?p=1048, diunduh pada 11 Juli 2014. 